\title{
THE AFRENTA DE CORPES: EMBODIED EMPATHY IN CANTAR DE MIO CID
}

\author{
Luis F. LóPEZ GoNZÁLEZ \\ 1f.1opez@vanderbilt.edu \\ Vanderbilt University, EE. UU.
}

The poet's grief-stricken address to his audience while describing the brutal beating of Mio Cid's daughters in the forest of Corpes (afrenta de Corpes) demonstrates the author's goal to move his listener to empathy: «Por muertas las dexaron, sabed, que non por bivas./ ¡Cuál ventura serié si assomás essora el Cid Campeador!» (vv. 2752$2753)^{1}$. The poet synthesizes the inhuman battering of Mio Cid's daughters with the assertion that the Infantes de Carrión left them for death. The dramatic intensity of his account is so fraught that he disrupts the flow of his narrative to seize the attention of his public by addressing them informally, interjecting «sabed», a directive that invites his audience to imagine the harrowing violence, hence appealing to their cognitive empathy. The direct address suggests that the minstrel wants to move his immediate audience to reflect upon the brutality perpetrated against two innocent - if not saintly-ladies and devoted wives. The second verse expresses the poet's longing for Mio Cid to appear as Deus ex machina to rescue his daughters and punish the evildoers. Whereas the first verse appeals to the emotions of the audience, the second represents a manifestation of the author's empathy toward the victims.

The purpose of this study is to show how the Cid-poet uses narratological devices extant during his time as means of evoking an empathetic response from his audience. Contemporary theories of «embodied cognition» (the notion that brain and body are interconnected) suggest that readers respond differently to affective stimuli when confronted with situations in which literary characters feel pain or pleasure, depending on how deeply they identify with the characters represented. The simultaneous action of humanizing victims and dehumanizing perpetrators allows such identification to occur. These contemporary theories of embodied cognition, which we will refer to only when relevant, have clear precursors in classical treatises on rhetoric and poetry. To demonstrate that the Cid-poet seeks to produce a psycho-affective identification with the victims, Doña Elvira and Doña Sol, while demonizing the Infantes, this study draws

${ }^{1}$ All references come from Alberto Montaner's ed., Cantar de Mio Cid, Barcelona, Crítica, 2007. From now on, I provide the verse numbers in the body of the text. 
from classical treatises of rhetoric and poetry that the poet may have known. This approach will allow us to map out the discourses employed by the poet, which portray him as an empathetic storyteller who attempts to elicit a similar emotional response in his public.

The concepts of ethos and pathos go as far back as Plato and Aristotle, and medieval poets exploited these rhetorical devices for dramatic purposes well before the composition of the Cantar de Mio Cid. Let us recall the extreme cognitive distress Saint Augustine feels for Dido's unrequited love and subsequent suicide after the saint reads Virgil's Aeneid ${ }^{2}$. Shakespeare, who has drawn from Quintilian's manual on rhetoric to embellish his plotline, also exploited these discursive tools for dramatic gain, as shown by Hamlet's angry outburst after watching the performers stage Hecuba's display of grief after observing her husband's shameful death («what's Hecuba to him or he to Hecuba/ that he should weep for her» Act II, Scene 2), while Hamlet, who has a valid reason to feel real emotions, remains (im)passive before the tragic loss of his father. The Cid-poet may have read Saint Augustine's De civitate Dei, and, based on his pragmatic knowledge of jurisprudence and rhetoric, he likely read the Hispano-Roman Quintilian's De institutio ${ }^{3}$. One can say with Charles F. Fraker, who invokes Ben Jonson, that «Quintilian is all a poet needs... more or less $\rangle^{4}$. It is true for Fernando de Rojas, Fraker asserts, and it is also true for the author of the Cantar. Indeed, parts I and II of Book 6 of Quintilian's treatise are designed to help orators/ performers achieve a mastery in moving and persuading the audience during hearings and trials. Quintilian's expository tract, which in turn, borrowed many of its theories from Horace's Ars poetica, also serves as a dramatic handbook of sorts for performers and playwrights to manipulate the feelings and cognitive responses of others.

In his analysis of the performativity of ethos and pathos, Quintilian translates the Greek term pathos into Latin as adfectus (emotion),

\footnotetext{
${ }^{2}$ In his Confessions I, 21, Saint Augustine regrets that he has been forced to learn about Aeneas's wanderings, and neglecting his own, «and to weep for Dido's dying (plorare Didonem mortuam), just because she killed herself for love». Carolyn J. B. Hammond, ed. and trans., Augustine. Confessions, vol. I. Cambridge, MA, Harvard UP, 2014, p. 37. Helen Waddell asserts that Augustine «broke his heart for Dido», quoted by John Ó’Meara, "Virgil and Augustine: The Aeneid in the Confessions», The Maynooth Review, 13 (1988), pp. 30-43 (p. 36).

${ }^{3}$ The Cid-poet demonstrates adroitness in the theories of law and drama. Colin Smith has shown that Per Abbat exhibits a thorough knowledge of pragmatic jurisprudence, which leads him to speculate that the Cid-poet was a bilingual lawyer practicing in Burgos in the early thirteenth century. Colin Smith, The Making of the Poema de Mio Cid, Cambridge, Cambridge UP, 1983, pp. 79-83. In another study, Smith notes that Mio Cid is «a skilled lawyer, [and] an eloquent speaker at court». Colin Smith, «Did the Cid Repay the Jews?», Romania, 86 (1965), pp. 520-538 (p. 28). Like Colin Smith, Peter E. Russell's examination of the complex legalistic discourses leads him to conclude that the author of the Cantar was at least «interested in legal matters and in the sort of documents by which the processes of civil and military administration were carried on in his time». Peter E. Russell, «Some Problems of Diplomatic in the Cantar de Mio Cid and their Implication», The Modern Language Review, 47 (1952), pp. 340-349 (p. 349).

${ }^{4}$ Charles F. Fraker, Celestina: Genre and Rhetoric, London, Tamesis, 1990, p. 77.
} 
and ethos as a close equivalent of mores (morals). Pathos is a violent adfectus, and ethos represents more calm and gentle emotions. If pathos evokes powerful passions, ethos educes subdued feelings. Quintilian asserts that pathos «commands and disturbs», and ethos «persuades» and induces a sense of goodwills. While the latter is continuous, the former is sudden, but more powerful. The binary pathos-ethos parallels the Stoic dichotomy ira-ratio (anger-reason). The fleeting but awe-inspiring quality of pathos resembles that of ira, which Horace described in Epistulae I, 2, 62 as a transient madness («Ira furor brevis est») ${ }^{6}$, and reason as a governing principle of civilized societies. In order to move the audience to pity and tears, the performer must strike a perfect balance between ethos and pathos. Quintilian posits that drawing an ekphrastic, articulate ethopoeia (Greek term meaning the creation of character traits in rhetoric) of antagonists falls within the domain of ethos because it requires a rational, calm, and persuasive description of their personalities:

It is quite right also to use the word ethos of the sort of school exercises in which we often represent countrymen, superstitious men, misers, and cowards according to the terms of our theme. For if ethos means mores, then when we imitate mores we base our speech on ethos ${ }^{7}$.

If the representation of a person's character has to be portrayed through rational discourse, pathos represents emotional descriptions that would touch the heart of the audience. With pathos, the performer magnifies the critical moments of the account, seeking to shake the listener to his core. Quintilian uses the Greek term deinosis («making terrible»), which serves the purpose of «arousing emotion which is not there or in making an existing emotion more intense ${ }^{8}$. Anticipating the contemporary concept of empathy, Quintilian asserts that by using deinosis, the performer can magnify events that would prompt the listener to identify and commiserate with victims' plight. In his Poetics, Aristotle had already stressed the employment of awe-inspiring descriptions in tragedies to shock the spectator ${ }^{9}$, which is more effective when the «fearful and pitiable» stem from «the actual structure of the events $»^{10}$. In other words, the events designed to shake the audience's consciousness ought to arise organically from

${ }^{5}$ Donald A. Russell, ed. Quintilian. The Orator's Education, Cambridge Mass, Harvard UP, 2001, p. 49.

${ }^{6}$ H. R. Fairclough, ed. Horace. Satires, Epistles, Art of Poetry, Cambridge Mass, Harvard UP, 1929, p. 266.

${ }^{7}$ Donald A. Russell, Quintilian.., op. cit., pp. 53 and 55.

${ }^{8}$ Ibid., p. 57.

${ }^{9}$ Stephen Halliwell (ed. and trans.), Aristotle. Poetics, Cambridge Mass, Harvard UP, 1995, p. 63.

${ }^{10}$ Ibid., p. 73. 
the plotline and have an internal logic. Aristotle asserts that a crime committed by one family member against another would create a greater affective impact in the public because of its heightened moral reprehension ${ }^{11}$. Quintilian, who had likely read Aristotle's Poetics, gets closer to the matrix of what contemporary scholars of cognitive theory call embodied empathy, namely, a reader's ability to project him/herself onto a literary character ${ }^{12}$, and not only understand, but actually feel his/her pain:

Again, when pity is needed, let us believe that the ills of which we are to complain have happened to us, and persuade our hearts of this. Let us identify with the persons of whose grievous, undeserved, and lamentable misfortunes we complain; let us not plead the case as though it were someone else's, but take the pain of it on ourselves for the moment. We shall thus say what we would have said in similar circumstances of our own ${ }^{13}$.

The performer, just as the actors performing for Hamlet do, must virtually enter into the victim's subjectivity to understand and feel what he/she may have felt in order to make others feel the grief of the sufferer. Horace, who states that performers can «lead the hearer's soul where they will», sums this up in the dictum of his Ars poetica: «Si vis me flere, dolendum est/ primum ipsi tibi» [«if you would have me weep, you must first feel grief yourself»]. Only by partaking in the victim's sorrows, the Roman poet avers, will the performer's words hurt him («tunc tua me infortunia laedent») $)^{14}$. Quintilian, who had studied Horace's Ars poetica carefully ${ }^{15}$, is crafting a blueprint to help the poet not only lay the groundwork to move his audience to tears by identifying with sufferers, but to actually project him/ herself onto the victim. The artist must create the illusion - not that he is re-enacting the crime but-that he is experiencing the pain that the victim had felt. As Malcolm K. Read has remarked, the Cid-poet deploys vivid imagery to conjure up the horror lived by Mio Cid's

${ }^{11}$ Aristotle avers: «what tragedy must seek are cases where the sufferings occur within relationships, such as brother and brother, son and father, mother and son, son and motherwhen the one kills (or is about to kill) the other, or commits some other such need». Stephen Halliwell, Aristotle. Poetics, op. cit., p. 75. The Cid-poet follows this dramatic directive, and makes the husbands nearly kill their wives.

${ }^{12}$ Theory of Mind (ToM) - the primary line of inquiry of cognitive studies - , the ability to identify with and partake in the pain and joy of fictional characters, helps us comprehend the essential aspects of drama and the spectators' responses to what they perceive on stage. For some hypotheses on ToM see Lisa Zunshine, «Introduction», in Introduction to Cognitive Cultural Studies, Baltimore, Johns Hopkins UP, 2010, Suzanne Keen, «A Theory of Narrative Empathy», The Ohio State University Press, 14.3 (2006), pp. 207-236, and for its application to Spanish Renaissance literature, see the collection of studies edited by Isabel Jaén and Simon J. Julien, Cognitive Approaches to Early Spanish Literature, Oxford, Oxford UP, 2016.

${ }^{13}$ Donald A. Russell, Quintilian. The Orator's Education, op. cit., p. 63, emphasis added.

${ }^{14}$ H. R. Fairclough, Horace. Satires, op. cit., pp. 458-459.

${ }^{15}$ See H. R. Fairclough, Ibid., p. 442. 
daughters during the aggression, including the image of the spilt blood: «the bard was a master of his art and well knew how to arouse a sense of outrage in his audience ${ }^{16}$. To convey the sorrow of Mio Cid's daughters, therefore, the poet employs this Horatian-Quintilian rhetorical mechanism of first feeling the pain before attempting to elicit a similar response in his audience.

\section{EMBODIED EMPATHY IN THE CORPES STORY}

Just as he sets out to create Rodrigo's character with the mold of the epic hero, the Cid-poet fashions the Infantes to be the villains of the Cantar $^{17}$. Thomas R. Hart, who notes the poet's effort to engage the audience's empathy toward Mio Cid from the onset, remarks that the poet does not design his characters based on authorial objectivity associated with the epic genre. Rather, he forms his characters as means of controlling the audience's opinions ${ }^{18}$. Similarly, Peter N. Dunn notes that the juglar purposefully narrates dramatic scenes in order to engage and enhance «the emotions of the audience ${ }^{19}$. Both in creating characters and developing storylines, the poet considers the affective reactions of his public.

The characterization of the Infantes attests to Hart's and Dunn's assertions. No other characters, including Moors, Jews, and Catalans, in the Cantar are introduced to the spectator in such negative light. The poet, who often appeals to his audience's adfectus by addressing them directly, has been predisposing his listener to dislike the Infantes, underscoring their egotism, duplicity, and greed from the $\operatorname{start}^{20}$. Even before the Infantes speak, the reader knows about their duplicity and depravity, which the author stresses by revealing their corrupt intentions in marrying Mio Cid's daughters. They are driven by greed and selfishness, rather than by the desire to start a family to serve the king and God. The poet reiterates the Infantes' self-serving intentions multiple times, just as he repeats their plan to brutalize their wives in the oak-forest of Corpes. The deliberate emphasis on the Infantes' wicked intentions in marrying, and then in battering their wives can be construed as a premeditated strategy to elicit empathy toward the victims and antipathy toward the Infantes.

\footnotetext{
${ }^{16}$ Malcolm K. Read, The Birth and Death of Language: Spanish Literature and Linguistics: 1300-1700, Madrid, José Porrúa Turanzas, 1983, p. 10.

${ }^{17}$ Smith perceptibly asks «why did the poet, needing villains, choose the Infantes de Carrión?» Attributing the poet's display of antagonism toward the Infantes to possible historical conflicts between Carrión and Burgos, «The Choice of the Infantes de Carrión as Villains in the Poema de mio Cid», Journal of Hispanic Philology, 4 (1980), pp. 105-118 (p. 106).

${ }^{18}$ Thomas R. Hart, «The Rhetoric of (Epic) Fiction: Narrative Technique in the Cantar de Mio Cid», Philological Quarterly, 51.1 (1972), pp. 23-35 (pp. 23-35).

${ }^{19}$ Peter N. Dunn, «Theme and Myth in the Poema de Mio Cid», Romania, 83 (1962), pp. 348-369 (p. 349).

${ }^{20} \mathrm{John}$ Walsh, «Performance in the Poema de mio Cid», Romance Philology, 44.1 (1990), pp. 1-25 (p. 5).
} 
Shortly after the Infantes' humiliating attitude during the lion's escape and their cowardly flight when facing King Búcar's soldiers in battle, Diego and Fernando secretly conspire to remove their wives from Valencia with the purpose of abusing them, or at worst, killing them:

Vayamos pora Carrión, aquí mucho detardamos.

Los averes que tenemos grandes son e sobejanos, mientra que visquiéremos despender no los podremos.

Pidamos nuestras mugieres al Cid Campeador, digamos que las levaremos a tierras de Carrión, e enseñarlas hemos dó las heredades son.

Sacarlas hemos de Valencia, de poder del Campeador; después en la Carrera feremos nuestro sabor, ante que nos retrayan lo que cuntió del león. Nós de natura somos de condes de Carrión, averes levaremos grandes que valen grant valor, escarniremos las fijas del Campeador.

D'aquestos averes sienpre seremos ricos omnes, podremos casar con fijas de reyes o de enperadores, ca de natura somos de condes de Carrión.

Assí las escarniremos a las fijas del Campeador antes que nos retrayan lo que fue del león.

(vv. 2540-2559, emphasis added)

The first verse reveals the Infantes' intention to escape with the wealth that Mio Cid has bestowed upon them. Returning to Carrión echoes the classic motif of the warrior's homecoming after a long period of war and successful victories, as Mio Cid in his return to Castile - although not to his hometown of Vivar - after conquering large swaths of land-including Valencia-from the Moors. In the Infantes' case, it is a reversal of the mighty hero returning home. The Infantes have been unable to adapt to their life in Valencia and the demands of the Valencian court. For the cowardly brothers, Valencia represents a locus of wealth, but also of dangers for which they are miscast to face. Carrión is their comfort zone, with no pressure to be heroic warriors; this idea is evoked in the third verse, which suggests that their fear of war will prevent them from ever enjoying their acquired wealth. The second verse highlights their obsession with money, but what is meant to provoke an emotional reaction in the audience is their deceitful conspiracy against the hero's daughters. They purport to take them to Carrión to show them their possessions, but they secretly plan to defile them. These duplicitous traits reveal the poet's understanding of human psychology. The Infantes say one thing when they mean the opposite. 
The Infantes connive to detach their wives from Mio Cid's protection. Once Mio Cid cannot defend them, they can do anything they want to them. Whether they want to kill them or not, as Roger M. Walker and Colin Smith respectively argue ${ }^{21}$, remains unclear from the Infantes' words and subsequent actions. But noble ladies, as Doña Sol would make clear, preferred death to rape or ignominy. The Infantes remind themselves of their inherent nobility to put themselves above Mio Cid and his daughters. The author makes the Infantes refer to their wives as Mio Cid's daughters, and not as their wives, which suggests a sense of rejection and even a disavowal of their matrimonial vows. They repeat this assertion twice, and they are in the same verses in which they reiterate their violent plan: «Escarniremos las fijas del Campeador», and «assí las escarniremos a las fijas del Campeador». The Infantes discursively alienate their wives as means of justifying their impending crime. In their minds, they will not defile and dishonor their wives, but the daughters of a perceived enemy. The poet makes the Infantes repeat many of the same formulaic concepts and ideas that stress not only their mens rea, but also their inability to express their thoughts with clarity. Their failure to communicate in an eloquent manner, which foreshadows to the incoherence of their older brother, Asur González, as he enters inebriated into the cortes of Toledo (vv. 3373-3376) 22 $^{22}$, is a reflection of their inability to control their passions. After they express their intentions to abuse and dishonor their wives the first time, they hubristically claim that they could marry the daughters of kings and emperors since they are royalty by blood.

Just as the Infantes disavow their wives to justify their attack, the author poetically alienates the Infantes from his audience. The poet would likely belong and speak to the common people. He is underlining the Infantes' self-proclaimed nobility, depicting them as corrupt and greedy cowards. But most importantly, the author is revealing their foul intentions to influence the audience's reactions. In the Insititutio, Quintilian recommends that the performer emphasize the antagonist's premeditation to appeal to the audience's sense of indignation. Hatred toward the evildoer can be enhanced «if the attack was not a mistake or a blow in anger (or, if in anger, the anger was unjustified $[\ldots)] \gg^{23}$. Quintilian's advice to stress intentionality is informed by a keen knowledge of psychological responses that trigger the emotions that generate either anger or empathy.

${ }^{21}$ Colin Smith contends that the Infantes do not intend to kill their wives, arguing that they would have killed them if they had intended to. Walker, however, proposes that the Infantes want to kill them, basing his arguments on external sources as well as rather weak textual references from the Cantar. Colin Smith and Roger M. Walker, «Did the Infantes de Carrión Intend to Kill the Cid's Daughters?», Bulletin of Hispanic Studies, 56/1 (1979), pp. 1-10.

${ }^{22}$ See also Thomas Montgomery, «The Presence of a Text: The Poema del Cid», Modern Language Notes, 108.2 (1993), pp. 199-213 (p. 203).

${ }^{23}$ Donald A. Russell, Quintilian. The Orator's Education, op. cit., p. 27. 
Even before Mio Cid consents to let his daughters depart from Valencia, the poet is foreshadowing the afrenta, and laments: «De assí ser afontado no·s' curiava el Campeador» (v. 2569). Both Mio Cid and his daughters are unaware of the humiliation and brutality («afontado») by the very men charged to protect them. The audience, however, is informed of the event before it takes place, which helps build the dramatic tension and create an anticipated sense of anger in the public. In order to foil the wickedness of the Infantes, the poet reiterates Mio Cid's largess and bona fide affability. The hero confers upon the Infantes an enormous amount of money and other valuables, including his two swords, Colada and Tizón because he sees and treats them as his sons (v. 2577). But most importantly, he entrusts them with the wellbeing of his daughters whom Mio Cid refers to as his heartstrings: «Allá me levades las telas del coraçón» (v. 2578), a fraught expression that the hero reiterates during the cortes de Toledo (v. 3260) to move King Alfonso and his court to pity and anger. This evocative metaphor renders the crime more heinous not only because of the betrayal and abuse of two innocent ladies, but because his daughters are an extension of the Cid himself.

Despite his purported affection toward his sons-in-law, Mio Cid presages the tragedy. Inexplicably he does not prevent them from leaving (vv. 2615-2617). His presentiment, however, prompts him to send his nephew Félez Muñoz to keep them company until they arrive at Carrión. While they are en route to Carrión and before entering the Robledo of Corpes, the treasonous Infantes contrive to kill Mio Cid's Moorish friend and ally Avengalvón to divest him of his wealth. After Avengalvón discovers the plot, he suspects the Infantes' crime, and tells the Infantes that he does not return Doña Elvira and Doña Sol to Valencia out of respect for Mio Cid (v. 2677). Ulrich Leo affirms that if Avengalvón had stopped them from committing the crime against their wives, the Cantar would have ended ${ }^{24}$. The Afrenta de Corpes, as Leo suggests, is a climactic episode that shapes both the outcome of the story and the Cantar as a whole.

After bidding them farewell, Mio Cid returns to Valencia with extreme physical and psychological pain: «Cuemo la uña de la carne ellos partidos son» (v. 2642). The image of somatic agony of separation, evoked by the simile cuemo la uña de la carne, which had already been expressed during the farewell of Mio Cid and his family in Cardeña (v. 372), vividly stresses the bonds of blood and love between the hero and his infant daughters. The psychosomatic pain that the poet expresses through this well-crafted simile is redolent of the cognitive pain the poet and his audience feel, knowing that the innocent ladies are about to be assaulted. Thomas Montgomery states

${ }^{24}$ Leo [Ulrich is the first name, not the family name], «La Afrenta de Corpes, novela psicológica», Nueva Revista de Filología Hispánica, 13.3 (1959), pp. 291-304 (p. 298). 
that «the poet knows his own feelings, and identifies them with those of the hero and audience ${ }^{25}$. As creator and conveyor of his poetic world, the author has the power to regulate or even manipulate his emotional responses as means of influencing those of his public, as it becomes evident during his emotive recitation of the violent episode in Corpes.

The Infantes and his entourage enter the robledo of Corpes at dusk. The description of the terrain serves the purpose of preparing the reader to witness the tragedy. As mentioned above, the audience already knows the Infantes' sordid plan to harm their wives, but they do not know when and how it will occur. The Infantes have traversed multiple towns and forests without a thorough description of the place. When the author describes the ominous nature of the robledo, the audience can sense that the tragedy is near. The poet helps his audience anticipate the abuse by defining the place with the leitmotif of the locus terribilis:

Entrados son los ifantes al robredo de Corpes, los montes son altos, las ramas pujan con las núes, e las bestias fieras que andan aderredor. Fallaron un vergel con una linpia fuent, mandan fincar la tienda ifantes de Carrión, con cuantos que ellos traen ý yazen essa noch, con sus mugieres en braços demuéstranles amor, ¡mal ge lo cunplieron cuando salié el sol! (vv. 2697-2704)

Within the locus terribilis, they find a locus amoenus, which is a recurrent motif in courtly love discourses ${ }^{26}$. The topographic contrast parallels the moral polarity of the Infantes and their wives. The poet describes the spatial economy as surrounded by lurking beasts that threaten the physical safety of both the Infantes and their wives. In this context, however, the Infantes become even more dangerous than the feral animals. The wild landscape further serves as a metonymy of the Infantes' moral and spiritual states. The last two verses deploy yet another duplicitous trait of the Infantes' behavior. On the one hand, they show (demuéstranles amor), which is a euphemistic phrase for the sexual act, but on the other, this display of affection merely serves as foil and preface for their act of cruelty that will follow the next morning.

${ }^{25}$ Thomas Montgomery, «The Poema de Mio Cid: Oral Art in Transition», in Mio Cid Studies, ed. Alan D. Dayermond, London, Tamesis, 1977, pp. 91-112 (p. 100).

${ }^{26}$ For an analysis of courtly codes in Cantar, see Michael E. Gerli, «Liminal Junctures: Courtly Codes in the Cantar de Mio Cid», in Oral Tradition and Hispanic Literature. Essays in Honor of Samuel G. Armistead, ed. Mishael M. Caspi, New York, Garland Publishings, 1995, pp. 257-270. 
When the Infantes resolve to abandon their wives in the inhospitable and dangerous robledo of Corpes, they send their entourage ahead. Again, they exhibit an uncanny capability for duplicity and cruelty. They tell their associates that they want to stay a little longer to enjoy (deportarse) their wives, while in their minds, they are contriving their wives' demise:

Adelant eran idos los de criazón, assí lo mandaron los ifantes de Carrión, que non ý fincás ninguno, mugier nin varón, sinon amas sus mugieres, doña Elvira e doña Sol, deportarse quieren a todo su sabor.

Todos eran idos, ellos cuatro solos son, tanto mal comidieron los ifantes de Carrión. (vv. 2707-2713)

The reflexive verb «deportarse» means to enjoy or have pleasure, but the Infantes use the term to mean the opposite, unless they derive sexual gratification from inflicting pain on their victims, which would turn the afrenta into an act of sexual deviance. In this case, as in other instances of the Cantar, the reaction of the audience would depend upon the physical gesture of the bard as he is performing the episode. Dámaso Alonso pointed out that the juglar's mimicry would enhance the audience's responses ${ }^{27}$. If he winks with malice at the audience as the Infantes utter their design to «deportarse... a todo su sabor», the audience would have reacted with anger and antipathy, but if the words are unaccompanied by gestural expressions that denote deceit, the phrase would have been as ambiguous to them as it is for the contemporary reader. Bodily movement and facial expressions would help minstrels convey guilt and mens rea. Since the poet's purpose is to portray the Infantes as antiheroes, we can surmise that he employed all forms of performative tools at his disposal to convey the real intentions of the villains.

When everyone departs, the Infantes address their wives to torment them with their evil plot:

Bien lo creades, don Elvira e doña Sol, aquí seredes escarnidas, en estos fieros montes, oy nos partiremos e dexadas seredes de nós, non abredes part en tierras de Carrión.

Irán aquestos mandados al Cid Campeador, nós vengaremos por aquésta la del león. (vv. 2714-2719)

Ulrich Leo, who interprets the Infantes' display of brutal force by applying the contemporary concept «inferiority complex», calls

${ }^{27}$ Dámaso Alonso, «Estilo y creación en el Poema del Cid», in Ensayos sobre poesía española, Madrid, Revista de Occidente, 1944, pp. 16-26. 
the afrenta a «novela psicológica» ${ }^{28}$. Nowhere in the Cantar is human psychology weaponized as it is in this passage. The Infantes apply psychological torture before they employ physical violence. They repeat the word «escarnidas», which confirms that their threats to «escarnecerlas»—-which they had uttered twice before while they were planning their attack-were pronounced in earnest. The poet, subsequently, offers a vivid description of the brutality employed:

Alli les tuellen los mantos e los pelliçones, páranlas en cuerpos e en camisas e en ciclatones.

Espuelas tienen calçadas los malos traidores, en manos prenden cinchas fuertes e duradores.

Cuando esto vieron las dueñas, fablava doña Sol.

(vv. 2720-2724, emphasis added)

The author stresses the victims' undressing to accentuate their modesty and chastity. The act of uncovering, which is represented with anaphoric emphasis («en cuerpos e en camisas e en ciclatones»), serves a double purpose. First, exposing their bodies is an act of cruelty in its own right; public nudity of noble ladies is demeaning and shameful. Their nakedness also makes the victims self-conscious about their condition as female and therefore vulnerable. In hagiographical accounts, nudity was intimately linked to martyrdom and sadism. Beyond their nakedness, the poet offers a picture of the instruments employed to torture the vulnerable victims. They use espuelas and cinchas, both of which are mainly designed for animal ab-use, further evoking the dehumanization of the victims. Since the Infantes are traveling by horse, the author uses the image of the espuelas and cinchas to add verisimilitude to his story, but at the same time, both instruments are capable of inflicting excruciating pain on the sufferers. The spurs in particular, which are not designed to kick horses but to stimulate them, could easily cause the death of the victim, regardless of whether the offenders used them with their feet or their hands ${ }^{29}$. The Cid-poet is scrupulously trying to implant the image of the Infantes treating the noble ladies like animals in the mind of audience, which will cause the spectator to experience an enhanced empathy toward the victims. This kind of rhetorical device of implanting images into the minds of the listener to identify with the victims was known in Greek rhetoric as phantasiai (visions), by

${ }^{28}$ Leo intuitively contends that the Infantes commit their wicked act of violence because they are «"proyectando" infaliblemente sobre otras personas sus propios defectos, les hace sospechar, en cada palabra que se les dirige, un veneno oculto». Ulrich, «La Afrenta de Corpes», art. cit., p. 296.

${ }^{29}$ For a discussion as to whether the Infantes use their spurs with their feet or their hands, see Douglas Gifford's study in which he argues that the Infantes kick their wives with the spurs, «European Folk-Tradition and the Afrenta de Corpes», in Alan D. Deyermond (ed.), Mio Cid Studies, London, Tamesis, 1977, pp. 49-62. 
which «the images of absent things are presented to the mind in such a way that we seem actually to see them without eyes and have them physically present to us» ${ }^{30}$. The performer, whom Quintilian calls euphantasiostos, has to use deinosis to dialectically stage the murder scene before the eyes of the public to engage their emotions and heighten their aesthetic responses.

After offering a picture of the instruments of torture, the author makes Doña Sol address the Infantes. But most important of all, the narrator aims directly at the heart of the audience. Quintilian counsels orators to impersonate the victim and utter fictitious speeches as if the victims themselves had spoken the words ${ }^{31}$. The poet again slows down the pace of the narrative to actually make the sufferer speak, allowing the audience (both the Infantes and the bard's public) to feel pity and empathy for their plight. Incidentally, this is the only instance in the Cantar in which the narrator individualizes the voice of Mio Cid's daughters, and Doña Sol's words come in the moment of highest dramatic and psychological tension:
¡Don Diego e don Ferrando, rogámosvos por Dios! dos espadas tenedes fuertes e tajadores, al una dizen Colada e al otra Tizón, cortandos las cabeças, mártires seremos nós; moros e cristianos departirán d'esta razón, que por lo que nós merecernos no lo prendemos nós. Atán malos ensiemplos non fagades sobre nós; si nós fuéremos majadas, abiltaredes a vós, retraérvoslo han en vistas o en cortes.

$$
\text { (vv. 2725-2733, emphasis added) }
$$

The conduplicatio of words represents the most salient stylistic feature of this tirada. Doña Sol repeats the first person plural pronoun «nós» five times, and she juxtaposes it with the second person plural «vos», which she repeats three times. Knowing that their lives may be about to end, Doña Sol makes a clear distinction between a distant «vos» and an intimate «nós». With their impending death, both Doña Elvira and Doña Sol feel connected to their ontological selves. The repetition of «nós», both in internal and external rhyming positions, shows the inextricability of the sisters as a poetic unit. It is equally shocking that Doña Sol does not appeal to her husband's

\footnotetext{
${ }^{30}$ Donald A. Russell, Quintilian. The Orator's Education, op. cit., p. 61.

${ }^{31}$ Quintilian: «It is in these passages particularly that good service is done by Prosopopoeiae, that is to say fictitious speeches of other persons. When an advocate speaks for a client, the bare facts produce the effect; but when we pretend that the victims themselves are speaking, the emotional effect is drawn also from the persons. The judge no longer thinks that he is listening to a lament for somebody else's troubles, but that he is hearing the feelings and the voice of the afflicted, whose silent appearance alone moves him to tears». Donald A. Russell, Quintilian. The Orator's Education, op. cit., p. 31.
} 
clemency by calling to mind intimate moments from their married life. The reader never learns who has married whom, and the poet does not seem interested in untangling this dramatic knot-perhaps because personalizing the Infantes may cause empathy ${ }^{32}$. Hence Doña Sol appeals to an impersonal «vos», and not to the man with whom she has shared her life for more than two years-unless the minstrel wants his contemporaneous audience to infer that there were no good moments in their marriage.

The audience, despite the irreconcilability between the «nos» and the «vos», would not forget that it is the husbands of the victims who are trying to kill them. This family betrayal both hurt and angered the spectator: «Quedaban prendidos por la fuerza emocional de esta traición $»^{33}$. As noted above, Aristotle asserted that the violence perpetrated against a close relative would stir the emotions of the audience with more intensity. And actually seeing the person suffer unjustified violence enables the identification with the victim. The Cidian romance, "Al cielo piden justicia», stresses the sufferers' anguish, which seems to elicit the commiseration of an implied audience:

A sendos robles atadas
dan gritos que es compasión,
y no las responde nadie
sino el eco de su voz ${ }^{34}$.

This ballad paints a moving scene, and there is an explicit reference to the empathy evoked in those who heard their throbbing screams. Whereas the author of the romance highlights the aural as the sense that triggers the readers' empathy, the Cantar uses sight as its main sensorial perception to identify with the ladies. Doña Sol's words bring to the fore the courage and composure that her husband and her brother-in-law have never shown in battle or the court.

Doña Sol alludes to their martyrdom («mártires seremos nós»), which is significant in various ways. First, it emphasizes their double innocence, namely, their lack of guilt and lack of malice. Second, Doña Sol offers a heartfelt plea, not to spare their lives - just as

${ }^{32}$ Both Leo Spitzer and Edna Aizenberg suggest that the poet's use of two characters twinned into one represents a poetic effort to show them in a negative light. Along with Raquel and Vidas, the two Jewish moneylenders, the Infantes de Carrión are referred to as a poetic unit, and the two pairs are shown as conniving, greedy and murmuring, see Edna Aizenberg, «Raquel y Vidas: Myth, Stereotype, Humor», Hispania, 63.3 (1980), pp. 478-486. Like the Infantes and the Raquel-Vidas poetic unit, Mio Cid's daughters are nearly always represented as a twinned unit, but they do not exhibit the duplicity that the Infantes show throughout the Cantar.

${ }^{33}$ Francisco López Estrada, Panorama crítico sobre el Poema del Cid, Madrid, Castalia, 1982, p. 135.

${ }^{34}$ Carlos Ochoa, Romancero del Cid: ó, Colección de romances castellanos que tratan de la vida y hazañas de Rodrigo Díaz de Vivar, El Cid Campeador, París, Dramard-Baudry, 1870, p. 60 , vv. $5-8$. 
Christian martyrs never asked their executioners for their lives - but to grant them an honorable death. For martyrs, pleading for their lives was tantamount to disavowing God. Doña Sol's woeful assertion functions as a rhetorical deinosis, making their impending death more terrible in the minds of the pubic by invoking the binary Christian «martyrs» vis-à-vis pagan «executors».

The contemporaneous Spanish audience would have picked up on the dramatic cues that the poet seamlessly weaves into the fabric of his Cantar. The instruments, the nudity, and the Infantes' evilness would have been enough for the spectator to associate their torture with those of Christian martyrs. Doña Sol heightens the dramatic and pathetic impact by iterating their innocence. Doña Sol uses both ethos and pathos in her discourse to dissuade the Infantes from their evil intent, underlining their martyr-like virtue (pathos), and reminding them that their actions could have political and legal consequences (ethos). After noting that Doña Sol's pleas do not produce the hoped-for effect, the juglar would have acted out the assault before his audience's eyes:

Lo que ruegan las dueñas non les ha ningún pro, essora les conpieçan a dar los ifantes de Carrión, con las cinchas corredizas májanlas tan sin sabor; con las espuelas agudas, don ellas an mal sabor, ronpién las camisas e las carnes a ellas amas a dós.

Limpia salié la sangre sobre los ciclatones, ya lo sienten ellas en los sos coraçones.

¡Cuál ventura serié ésta, si ploguiesse al Criador, que assomasse essora el Cid Campeador! Tanto las majaron que sin cosimiente son, sangrientas an las camisas e todos los ciclatones.

Cansados son de ferir ellos amos a dos, ensayándos' amos cuál dará mejores colpes. Ya non pueden fablar don Elvira e doña Sol, por muertas las dexaron en el robredo de Corpes.

(vv. 2734-2748, emphasis added)

As the author narrates the battering, the visual and aural senses are enhanced by the employment of cinchas and espuelas as instruments of torture ${ }^{35}$. Beyond the sexual symbolism, the motif of the blood dripping down from their fine silks, which plays a major role in the plotline of La leyenda de los Infantes de Lara after the Infantes de Lara stain Doña Lambra's tocas and pannos («et de las

${ }^{35}$ Although the concept of torture did not exist during the composition of the Cantar, I refer to torture here as the infliction of intense pain and agony, both physical and psychological, which had been used from Antiquity through the Middle Ages as a mechanism to punish and coerce. 
feridas que dauan enell cayo de la sangre sobre las tocas et en los pannos de donna Llanbra, de guisa que toda finco ende enssangrentada») ${ }^{36}$, functions as a powerful poetic device to engage the public's emotions. As Connie Scarborough notes, «the fact that the women's blood may attract the wild creatures even more dangerous than the Infantes heightens the pathos of the scene $)^{37}$.

The poet's unfulfilled desire for the Cid to be present to save his daughters and punish the offenders attests to the level of affective involvement of the poet with his own narrative. The modernist poet and playwright Eduardo Marquina (1879-1946), who dramatizes the afrenta de Corpes in a play entitled Las hijas del Cid, explains that when he first read the pitiful invocation to Mio Cid, he felt emotionally swept away by the dramatic power of Doña Sol's words. He states that he felt the drama («sentí el drama») of the words that penetrated his soul, leading him to behold the vision of Mio Cid taking his wounded daughters into his arms and avenging the affront: «Pasó por mi alma la visión tremenda del Cid levantando con sus manos los cuerpos heridos y profanados de sus hijas, y extendiendo en el aire su mano vengativa, sin palabras $\gg{ }^{38}$. The image of Mio Cid embracing his wounded daughters that Marquina evokes is so overpowering that Marceliano Santa María Sedano portrays it with vivid and powerful expression in a painting titled, Las hijas del Cid (1908) ${ }^{39}$. Marquina is expressing his desire to intervene in (or even alter) the unfolding of the drama, which shows his high level of embodied empathy, on the one hand, and his interfering cognition (active desire by a reader to intervene in events narrated in a fiction to save a person in danger), on the other. Marquina's reaction as well as Santa María Sedano's aesthetic representation are not merely testaments to their refined sensibilities as gifted artists; rather, their cognitive responses are a manifestation of the author's ability to engage his audience in the poetic world he is performatively enacting.

The poet engages his audience's emotions and empathy discursively, but also grammatically. In his analysis of Mio Cid's farewell to his daughters, Eleazar Huerta notes that the poet uses the present and the preterit tenses interspersedly. The preterit represents the narratological formula of epic narratives, and the present serves to express the emotional subjectivity of the Cid. Huerta states that this alternation between the two tenses helps the poet convey the «intellectual»

\footnotetext{
${ }^{36}$ Ramón Menéndez Pidal, ed., La leyenda de los Infantes de Lara, Madrid, Imprenta de los Hijos de José M. Ducazcal, 1896, pp. 215-216.

${ }^{37}$ Connie Scarborough, «Geographical and Allegorical Settings: An Ecocritical Reading of Afrenta de Corpes in the Poema de Mio Cid», Mediaevistik, 24 (2011), pp. 111-123 (p. 117).

${ }^{38}$ Quoted by Ramón Menéndez Pidal, «Introducción», Poema de Mio Cid, Madrid, La Lectura, 1913, p. 67.

${ }^{39}$ I want to thank the kind and insightful reviewer for calling my attention to this painting.
} 
(ethos) and the «sentimental» (pathos) $)^{40}$. In the description of the beating, this phenomenon is even more evident. In addition to longing for external help, the author also employs the present indicative to bestow upon his account a sense of immediacy and subjectivity. He employs many verbs in the present tense that convey graphic images of violence (empiezan a dar, májanlas, lo sienten, cansados son de ferir, ensayándos', non pueden fablar) to give the impression that the brutality is occurring before the audience's eyes. In his study on temporality and the use of verb tenses in the Cantar, Stephen Gilman asserts that the temporal irregularity in the poem is due to the interpolation of a «visual» historical present ${ }^{41}$. The idea of a «visual present» has a preponderant role in the representation of the violent act. Quintilian asserts that performers have to paint a crime as if it were occurring at that very moment. The use of the present tense gives the impression of temporal and spatial proximity so that the audience has the sensation that the brutal abuse is taking place simultaneously as the minstrel narrates ${ }^{42}$. Montgomery remarks that the Cid-poet uses the present and past tenses interchangeably because his sense of time is not linear. For Montgomery, the author «feels himself to be present at an act as he recounts it, and expresses it in the present tense» ${ }^{43}$. Without using cognitive terminology, Montgomery intuitively interprets the poet's use of the present tense as a conduit through which he transports himself into his fictional world.

In a description that foreshadows Hamlet's words after the actor's rendition of Hecuba's lyrical expression, Quintilian advises the performer to feel the victim's pain in order to move his public to tears and emotion:

And if the mere delivery of the written words of another can so kindle them with imagined emotions, what shall we be capable of doing, we who have to imagine the facts in such a way that we can feel vicariously the emotions of our endangered clients? $?^{44}$

The idea of aesthetic self-projection onto others has been widely studied in cognitive literary theory. Suzanne Keen argues that oral storytellers take «advantage of our tendency to share feelings

${ }^{40}$ Eleazar Huerta, Poética del Mio Cid, Albacete, Ediciones de la Diputación de Albacete, 1990 [first ed. 1947], p. 193.

${ }^{41}$ Stephen Gilman, Tiempo y formas temporalis en el Poema del Cid, Madrid, Gredos, 1961, pp. 102-103.

${ }^{42}$ Quintilian: «This is how Caesar's toga, carried in his funeral, covered in blood, drove the Roman people to fury. It was known that he had been killed; his body lay on the bier; but it was the clothing, wet with blood, that made the image of the crime so vivid that Caesar seemed not to have been murdered, but to be being murdered there and then». Donald A. Russell, Quintilian.., op. cit., p. 33.

${ }^{43}$ Thomas Montgomery, «The Poema de Mio Cid», art. cit., p. 108.

${ }^{44}$ Donald A. Russell, Quintilian..., op. cit., p. 63, translator's emphasis. 
socially by doing the voices and facial expressions of characters $\rangle^{45}$, and Bruce McConachie reminds us that «projecting the self into imaginary worlds appears early in the normal development of Homo sapiens $\rangle^{46}$. This idea of projecting our own feelings onto literary characters is also present in literary criticism. René Girard declares that in Shakespearean drama "we not only misunderstand but understand other people by projecting our own sentiments upon them $)^{47}$. The Cid-poet's dramatic intuition and poetic sensibility prompt him to use these cognitive devices to enhance his audience's (and his own) responses. As we saw in v. 2752 quoted above, the author repeats verbatim his desire for Mio Cid to intervene, while addressing his audience: «Sabed», and he reminds them that the Infantes have left the moribund ladies for dead, a graphic description that the poet repeats multiple times.

When the Infantes satiate their violent drives, they depart from the robledo. As they are moving away, they boast about their despicable deed, which would have enraged both the audience and Mio Cid if he had heard them: «Por los montes do ivan, ellos ívanse alabando» (v. 2757). The Infantes are bragging that they should not have taken Mio Cid's daughters even as concubines. The Cid-poet reiterates their hubristic assertion twice more (vv. 2763 and 2824), and the Infantes have the audacity to repeat it during the Toledo trials to Mio Cid's face. The Campeador cannot come to save his daughters, as the heartbroken poet and Marquina longed for, but their cousin Félez Muñoz does come to aid them. Although Félez, who lacks the qualities of epic heroes, does not punish the Infantes for their unwarranted violence, he takes the wounded ladies back to Valencia. When Mio Cid sees his daughters on the verge of death, he pronounces a bitter lament: «Ca tan grant es la rencura dentro en mi coraçón» (v. 2915), which brings into the audience's memory the multiple times that Mio Cid has declared that his daughters are strings of his heart.

Heartbroken and offended, Mio Cid does not seek a violent revenge against the Infantes. He acts with «mesura» (ethos) rather than irrational impulse (pathos). Mio Cid arranges a trial against them in order to bring them to justice. King Alfonso consents to Mio Cid's desire to judge the Infantes' crime because his request is informed by a deep sense of justice and reason. During the trial, Mio Cid enumerates every single offense committed by the Infantes with an articulate and rational discourse ${ }^{48}$. This rhetorical mastery represents the

\footnotetext{
${ }^{45}$ Suzanne Keen, «A Theory», art. cit., p. 209.

${ }^{46}$ Bruce McConachie, «An Evolutionary Perspective on Play, Performance, and Ritual», TDR: The Drama Review: A Journal of Performance Sutdies, 55.4 (2011), pp. 33-50 (p. 38).

${ }^{47}$ René Girard, «The Crime and Conversion of Leontes in The Winter's Tale», Religion and Literature, 22 (1990), pp. 193-219 (p. 198).

${ }^{48}$ Mio Cid's rhetorical mastery and self-composure lead Colin, Smith to refer to Mio Cid as «a skilled lawyer», and «an eloquent speaker at court». Colin Smith, «Did the Cid Repay», art. cit., p. 528.
} 
most distinctive feature of Quintilian's use of the Greek term ethos in the Cantar. Mio Cid appeals to reason and the mores (morality) of the audience as a way of communicating his grievances, instead of displaying a passionate speech that could have prevented him from articulating a relatable defense. Through ethos, he persuades his audience that his complaint is rooted in the strictest rule of law and not on an irrational impulse triggered by his anger or wounded pride. However, in closing his case (peroratio), Mio Cid appeals to the audience's emotions and perhaps to their paternal instincts. When he levels the accusation of violence against the Infantes, the affected father pronounces the only expletive of the entire Cantar, calling them «canes traidores» (v. 3263). Mio Cid equates the evildoers to disloyal beasts, implanting the image of the Infantes as marauding animals so that the audience can make a connection between their bestial nature and the wild beasts that surrounded the oak-forest of Corpes. Mio Cid reminds them (both the Infantes and the spectators) that by defiling his daughters, they have torn apart the strings of his heart: «¿A qué·m” descubriestes las telas del coraçón?» (v. 3260), an awe-provoking metaphor he had used in verse 2578. Although the author makes Mio Cid speak to the Infantes, deep inside, his words are aimed directly at the heart of his audience. The «telas del coraçón» serves as a mnemonic reminder to the listeners that just as his heart has been torn by the transgression against his daughters and his honor, his words should move their hearts, and feel the harrowing pain he is feeling. The poet, then, makes Mio Cid appeal both to the audience's rational mind (ethos) and to emotions (pathos). He strikes the perfect balance between the two rhetorical concepts, thus swaying the audience to rule in his favor. At the end of the trial (and the Cantar), Mio Cid gets justice and recovers his honra, not because of an abstract notion of poetic justice, but because he has been able to appeal to his audience's hearts and minds.

In contrast to Mio Cid's display of rhetorical prowess, the Infantes represent a negative example of lawyering and persuasion. Rather than showing contrition and seeking forgiveness, they tell the king and nobles that they do not regret their brutal behavior: "Porque dexamos sus fijas aún no nos repentimos» (v. 3357). The Infantes downplay their criminal conduct. They do not say «we do not regret having nearly killed them». Instead, they misrepresent the scene as a simple act of abandonment for which they feel neither guilt, remorse, nor shame. Their lack of repentance serves as further proof that the jongleur does not want to enlist his audience's empathy toward the Infantes. Dunn notes that the «juglar creates a circle of admiration and sympathy for the hero, and the audience is drawn into the magic circle of sympathy $\rangle^{49}$. The poet is not only keeping the Infantes out

\footnotetext{
${ }^{49}$ Peter N. Dunn, «Theme and Myth», art. cit., p. 353.
} 
of the circle of sympathy; he is effectively condemning them to a life of shame and infamy. Only after they understand that their actions could cost them their lives, do they repent. But their repentance is rather insincere and late.

During the trial, the Infantes reiterate that they belong to royalty and deserve to marry daughters of kings and emperors. These hubristic arguments, which are not rooted in legal principles, appeal neither to the mind (ethos) nor the heart (pathos) of the spectators. On the contrary, it makes the Infantes look petty and heartless, and these human qualities are rather used to repel cognitive empathy. In the end, the court rules against them, leading them to lose everything they had deemed important in life: money, honor, and political power. But, most important of all, the audience (both outside and inside the Cantar) has branded them as two antipathetic characters unworthy of nobility. At the end of the poem, the author describes the humiliating defeat of the Infantes in the feat of arms against Mio Cid's men as shameful (biltança). But more than trying to show the dishonor of the Infantes, their final defeat represents an aesthetic catharsis for Mio Cid, his daughters, the performing jongleur, his audience, and even for the modern reader. After causing distress in the audience, the poet punishes the Infantes and rewards Mio Cid's daughters by remarrying them to the princes of Aragón and Navarra, a happy ending that gives the minstrel's public a sense that justice is served to all.

The Cid-poet, inter alia, recounts the afrenta de Corpes to make his audience commiserate and feel the pain of the victims. Perhaps following Quintilian's rhetorical treatise, the author uses ethos and pathos to enhance the aesthetic identification with and self-projection onto the innocent ladies. Mio Cid's reaction both before and during the trial is merely an example of how the minstrel's public might have responded when confronted with such gruesome and unrepentant cruelty. The epithet that the hero hurls against the Infantes («canes traidores») could (or may) have been said by (m)any in the audience. Similarly, Mio Cid's psycho-affective reaction and emotional responses attest to the power that oral or written discourses can have in others. Rodrigo, like the bard's audience and modern readers, only hears the account from a third party since he is not present during the attack. Hence, the anger displayed by the heartbroken father and by those present during the trial in Toledo is but a reflection and a manifestation of the success of the poet in recounting the story. In the end, Doña Elvira and Doña Sol become princesses of Aragón and Navarra. Their social position becomes higher than the Infantes', which would have wounded the Infantes' sense of pride, while rewarding the audience by stressing the Christian ideal that good always trumps evil. 
$\cos$

THE AFRENTA DE CORPES: EMBODIED EMPATHY IN CANTAR DE MIO CID

\begin{abstract}
This study is an effort to understand the ways in which the poet of the Cantar de Mio Cid employs rhetorical devices as a way of enhancing the embodied empathy in his audience. I look into theories of performativity extant during the composition of the Cantar that the Cid-poet may have utilized to heighten the dramatic effect of his poem. The Hispano-Roman rhetorician, Quintilian, offers a guideline for orators and performers on how to put themselves «in the shoes» of abused victims and in doing so, move their audience to tears and/or anger. Following these rhetorical strategies, the author of the Cantar stages a performative act of the Afrenta de Corpes, in which the Infantes de Carrión nearly killed their wives, to move the public to feel the harrowing pain of the victims as their own as well as intense anger toward the evildoers.
\end{abstract}

KeYwords: Embodied empathy, cognitive studies, Robledo de Corpes, Mio Cid, Infantes de Carrión.

\title{
LA AFRENTA DE CORPES: EMPATÍA ENCARNADA EN EL CANTAR DE MIO CID
}

RESUMEN: Este estudio intenta entender las formas en las que el poeta del Cantar de Mio Cid emplea herramientas retóricas como una manera de aumentar la empatía encarnada en su audiencia. Me centro en teorías de performatividad vigentes durante la composición del Cantar que el poeta cidiano pudo haber utilizado para intensificar el efecto dramático de su poema. El retórico hispano-romano Quintiliano ofrece un manual con normas para oradores y artistas sobre cómo ponerse «en la piel» de las víctimas de violencia y, al hacerlo, mover a la audiencia al llanto o a la rabia. Siguiendo estas estrategias retóricas, el autor del Cantar monta un acto performativo de la Afrenta de Corpes, en la cual los Infantes de Carrión casi asesinan a sus esposas, para mover al público a sentir el dolor desgarrador de las víctimas, así como a sentir una furia intensa hacia los culpables.

Palabras Clave: empatía encarnada, estudios cognitivos, Robledo de Corpes, Mio Cid, Infantes de Carrión. 